\title{
A PATERNIDADE SOCIOAFETIVA E SEUS EFEITOS NA OBRIGAÇÃO DE PRESTAR ALIMENTOS AOS FILHOS AFETIVOS
}

\author{
Mariana Zomer de Albernaz Muniz'
}

Resumo: $O$ encargo alimentar visa à manutenção vital do alimentando com base no princípio da dignidade da pessoa humana, presente no atual texto constitucional. Posto isso, este trabalho busca esclarecer aspectos da família afetiva, seus deveres e obrigações, comparando analogicamente o pai afetivo ao biológico. Demonstrar-seá, portanto, a evolução do ordenamento jurídico brasileiro no âmbito do Direito de família que, mesmo esboçando grande avanço, não acompanhou plenamente as modificações ocorridas na sociedade, uma vez que se constata a ausência de normatização acerca da paternidade socioafetiva, assunto este cuja regulamentação ainda permanece relegada à doutrina e jurisprudência.

Palavras-chaves: Alimentos. Filiação. Igualdade. Direito.

\section{INTRODUÇÃO}

Antigamente, a realidade sócio-econômica era de uma época em que o cuidado com os bens de família era mais importante do que o reconhecimento de filhos havidos fora do casamento. Existia distinção entre os filhos biológicos e os adotivos, as mulheres não possuíam muita importância econômica, pois

1 Bacharel em Direito pelo Centro Universitário Curitiba - Unicuritiba. Advogada. Aluna da Escola Superior da Magistratura de Santa Catarina - ESMESC. Email: marizomer@hotmail.com 
não trabalhavam e assim, não aumentavam a fortuna familiar. Os filhos eram criados para terem profissões e casamentos direcionados à continuidade de uma família de caráter patriarcal e transpessoal.

Assim, a instituição do casamento delimitava os descendentes que tinham direitos ou não, sob a ótica jurídica, dos frutos dele provenientes. Os filhos nascidos fora da constituição do matrimônio eram renegados pela sociedade.

Contudo, muito se avançou no Brasil acerca desse pensamento. Com a evolução histórica, científica e revolucionária, esse conceito discriminante acerca dos filhos havidos fora do casamento foi mudando, dando vez a igualdade entre os descendentes, biológicos ou adotivos.

Juntamente com essa evolução social, as modalidades familiares se diversificaram e, consequentemente, se aprimoraram, fazendo com que o nosso ordenamento jurídico necessitasse também de alteração significativa para poder acompanhar tal progresso.

Com a Constituição Federal de 1988 e, posteriormente o Código Civil de 2002, nosso âmbito jurídico concernente a questões familiares mudou consideravelmente. Surge um novo ideal de família. A convivência e a vontade de constituir um vínculo familiar entre as pessoas prevalece sobre as questões biológicas. A proteção aos interesses afetivos e patrimoniais de cada integrante familiar torna-se prioridade.

Os princípios trazidos por essa Constituição Federal, encabeçados pelo princípio da dignidade da pessoa humana, trouxe a proteção à família eudemonista, afirmando a igualdade entre os filhos de qualquer origem e a proteção aos interesses da criança.

Hoje, é considerado família aquelas compostas por pais biológicos, pais fáticos, pais adotivos, monoparental, pais do mesmo sexo, sendo que em todos os casos há relação afetiva entre os componentes.

Decorrente deste novo entendimento, a doutrina jurídica especializada traz uma recente modalidade de paternidade (e 
filiação) denominada paternidade socioafetiva, traduzida na convivência familiar, independentemente da origem genética do filho.

Nesta linha, propõe-se no presente trabalho a evolução das relações familiares dentro do sistema jurídico brasileiro até o momento atual, onde há o reconhecimento da família socioafetiva e, consequentemente, a aplicação de seus efeitos jurídicos, especialmente no dever de alimentar o filho afetivo, decorrente princípio fundamental da dignidade da pessoa humana, da primazia à proteção dos interesses infanto-juvenis e do Estado Social Democrático de Direito.

\section{EVOLUÇÃO DA ENTIDADE FAMILIAR DENTRO DO ORDENAMENTO JURÍDICO BRASILEIRO}

A entidade familiar, seja no âmbito fático ou jurídico, traduzido pelo Direito de Família, passou por grandes transformações desde nossa primeira Constituição Federal até os dias de hoje.

Em nossa primeira Constituição, de 1834, a família era patriarcal e participava de forma restritiva no processo político, já que a capacidade eleitoral era medida conforme a capacidade contributiva de cada um, ou seja, somente participaram de sua construção pessoas do sexo masculino que possuíam alta participação econômica para com o Estado.

Assim,

(...) essa Constituição, por seu caráter não-intervencionista, não destinou normas especificas sobre a família brasileira, sua forma de constituição ou mesmo sua proteção, fatos que não deixam nenhuma duvida de que se harmonizava com o pensamento individualista predominante da época, enquadrando-se perfeitamente no modelo do liberalismo clássico².

2 OLIVEIRA, José Sebastião de. Fundamentos Constitucionais do Direito de Família. São Paulo: Revista dos Tribunais, 2002, p. 32. 
Antigamente, a idéia de família era traduzida como uma unidade de produção, decorrente da sociedade basicamente rural da época, onde o homem, autoritário, desempenhava o papel de chefe, enquanto que os filhos e a mulher eram vistos com inferioridade. A intenção era a proteção dos interesses familiares, que justificavam, inclusive, a celebração de casamentos arranjados, pouco importando a intenção pessoal do indivíduo. É marcante essa significação da família do passado mais como uma relação de poder do que como uma relação de afeto.

Posteriormente, nossa segunda Constituição, a Constituição da República dos Estados Unidos do Brasil, promulgada em 24 de fevereiro de 1891, também não trouxe um capítulo específico sobre a família. Apenas o $\S 4^{\circ}$ de seu art. 72, reconheceu o casamento civil, desde que sua celebração fosse gratuita.

Aqui ainda predominava o espírito da família patriarcal e o direito à cidadania continuava a ser concedido exclusivamente à pessoa do homem, mantendo-se a exclusão da mulher em relação a esse direito.

Assim, nossa segunda Constituição, também acentuadamente liberal e ainda defensora do individualismo como forma de realização pessoal, iniciou e terminou a sua vigência sem contemplar um capítulo destinado ao campo social e em especial sem ter dedicado uma proteção à família brasileira $[. . .]^{3}$.

Em 1916, surge o Código Civil Brasileiro, que igualmente abordava a família como sendo de cunho estritamente patriarcal, ligada diretamente ao casamento. A justificativa para essa concepção clássica seria em razão de uma necessidade natural humana de que os filhos deveriam obedecer aos pais e a mulher devia obediência ao marido.

Segundo Orlando Gomes, o entendimento jurídico era de que o "Direito de Família é o conjunto de regras aplicá-

3 lbid. p. 39. 
veis às relações entre pessoas ligadas pelo casamento ou pelo parentesco"4.

Contudo, caso não obtivessem sucesso na vida conjugal, o Código Civil de 1916 permitia o disquite, que nada mais era do que a separação de corpos, sem que com isso o casal interrompa o matrimônio.

Dessa forma, toda prole advinda de uma relação matrimonial era considerada legítima, garantindo assim a estrutura familiar decorrente da presunção pater is est, cujo significado é "que a maternidade é sempre certa e o marido da mãe é, normalmente, o pai dos filhos que nasceram da coabitação deles"

Com a Revolução de 1930 a consciência nacional clamava por uma nova ordem política, econômica e social, necessitando assim, uma nova constituição. $\mathrm{O}$ aumento das concentrações urbanas, o ingresso da mulher no mercado de trabalho e a mudança da condição social do jovem provocaram transformações nessa antiga ideia de família ideal.

A passagem do modelo econômico agrário ao industrial atingiu irremediavelmente a família, que se revelou não mais uma unidade de produção sob a autoridade de um chefe, e sim um grupo com divisão de funções definidas pelas aptidões individuais dos membros. Verifica-se profunda transformação ao longo do século XX, com sensíveis efeitos no meio familiar 6 .

Em 1932, um novo Código Eleitoral passou a vigorar. Segundo João Sebastião Oliveira, ampliando o direito de cidadania em nosso país, permitindo a participação das mulheres e das pessoas maiores de 18 anos no processo político, além

4 GOMES, Orlando. Direito de Família. Rio de Janeiro: Forense, 1978, p. 13.

5 LÔBO, Paulo Luiz Netto. Paternidade socioafetiva e o retrocesso da Súmula $n^{\circ} 301$ do STJ. Jus Navigandi, Teresina, ano 11, n. 1036, 3 maio 2006, p. 1. Disponível em: <http://jus.uol.com.br/revista/texto/8333>. Acesso em: 17-8-2011.

6 SILVA, Luana Babuska Chrapak da. A paternidade socioafetiva e a obrigação alimentar. Jus Navigandi, Teresina, ano 9, n. 364, 6 jul. 2004, p. 1. Disponível em: <http://jus.uol.com.br/revista/texto/5321>. Acesso em: 17-8- 2011. 
de prever o voto secreto e universal como forma de proteger a liberdade de expressão das pessoas?

Surge então, em 1934, a Constituição da República dos Estados Unidos do Brasil, que representou a transição do liberalismo clássico capitalista para o intervencionismo do Estado, trazendo em seu corpo normas relativas à alguns direitos sociais, além de se preocuparem em inserir a temática da família, da educação e da cultura.

Colhe-se que a matéria família foi tratada em alguns artigos (art. 113, n. 34, art. 134, art. 138, alíneas $b$ e $f$, e, arts. 144 a 147), entretanto, o poder constituinte apenas se limitou a especificar o ato pelo qual se constituía uma família, evidenciando que o casamento era indissolúvel, deixando de apresentar o verdadeiro sentido da entidade familiar, da substancialidade da instituição.

Em 1937 foi promulgada nova Constituição dos Estados Unidos do Brasil, apelidada de "A Polaca", tendo em vista a forte influência da Constituição da Polônia.O tema família sofreu pouca alteração da Constituição de 1934, permanecendo ausente um conceito sobre do que se constituía uma família para o direito constitucional e mantendo-se praticamente sem modificação na questão de cidadania.

Com o término da Segunda Guerra Mundial e vitória das democracias, desestabilizou-se os regimes totalitários ou autoritários em diversos países do mundo, incluindo o regime de governo implantado em nosso país, pelo então presidente Getúlio Vargas, denominado Estado Novo. Assim, logo após a posse do presidente Eurico Gaspar Dutra, no inicio de fevereiro de 1946, instalou-se a Assembléia Constituinte, com 328 constituintes que representavam várias correntes de opinião, criandose, em 18 de setembro de 1946, a Constituição dos Estados Unidos do Brasil. Segundo o jurista Luis Pinto Ferreira o novo texto constitucional "não aderiu ao socialismo nem tampouco

7 OLIVEIRA, op. cit., p. 42. 
se manteve na linha rígida do individualismo. Inspirou-se na técnica da democracia social weimariana"

Esta nova Constituição praticamente em quase nada inovou em relação à Constituição de 1934, tendo dedicado o Capítulo I, do Título VI ao tema família. Sampaio Dória extrai as seguintes conclusões:

1a) Somente o casamento de vinculo indissolúvel constitui a família;

2a) O casamento religioso equivale ao civil, se inscrito no registro público;

3a) A inscrição no registro público do casamento religioso poderá ser feita, seja a requerimento do celebrante ou de qualquer interessado, se o casamento tiver observado os impedimentos e as prescrições da lei, seja pelo próprio casal, mediante previa habilitação perante a autoridade competente; e

4a) Será gratuita a celebração do casamento civil”’.

Porém, no governo do presidente Castelo Branco houve algumas consideráveis modificações, por meio de emendas, no texto constitucional, fazendo com que o governo revolucionário entendesse por bem elaborar uma nova Constituição, dando luz à Constituição do Brasil, em 1967.

Sobre a família, o poder competente apenas referendou o que continha no Título IV do Anteprojeto, abrangendo o art. 167 e seus parágrafos, cujo teor, mais uma vez, não alterou a forma pela qual se admitia a constituição da família brasileira, merecendo proteção jurídica somente aquela constituída pelo casamento celebrado de acordo com a lei.

Com a implantação do regime militar no Brasil, nosso país recebeu a outorga de nova Constituição, através de uma

8 FERREIRA, Luis Ferreira. Curso de Direito Constitucional. 3 ed., São Paulo: Saraiva, 1974, v. I, p. 58.

9 DÓRIA, 1960, v. IV, p. 759-760 apud OLIVEIRA, op. cit., p. 58-59. 
emenda constitucional, por exercício do arbítrio dos ministros da Marinha de Guerra, do Exército e da Aeronáutica.

Ocorrendo o mesmo que nas Constituições anteriores, os responsáveis pela reforma da Constituição de 1967 não modificaram a forma da constituição da família nem se preocuparam em conceituar o que seria uma família para o direito constitucional. O tema está expresso no Título IV.

Em 1977, por meio de emenda constitucional, surgiu o divórcio, regulamentado pela Lei n. 6.515, de 26 de dezembro de 1977, deixando o casamento de ser indissolúvel, permitindo um novo vínculo matrimonial ao ex-cônjuge. A incorporação do instituto do divórcio foi um marco fundamental para o início da modernização do direito de família no Brasil.

Nenhuma outra alteração relevante no ordenamento jurídico brasileiro, até que, em 1985, Tancredo Neves foi eleito presidente do país sob o compromisso de redemocratizar o Brasil, visando oferecer uma reforma ampla nas instituições do país. Entretanto, acometido de doença, o então presidente veio a falecer assumindo o cargo de Presidente da República o VicePresidente José Sarney.

Essa nova era na vida política brasileira, chamada de Nova República, trouxe grandes e importantes medidas inovadoras ao país. As conseqüentes alterações sociais dificultam o acompanhamento do ordenamento jurídico brasileiro. Percebe-se claramente que, no Direito de Família, essa mudança social ocorreu de forma espantosa com significativas alterações.

A família conheceu - como nunca antes - sensíveis modificações em sua composição: 'As uniões 'legais' diminuem; a idade dos nubentes sobe; o numero dos filhos decresce; as roturas do vinculo matrimonial elevam-se (...)'. 'O problema da família aparece, assim, no centro da questão social do século XX - causa e conseqüência dela, como tem sido contemporânea das alterações sociais dos dois últimos séculos' ${ }^{10}$.

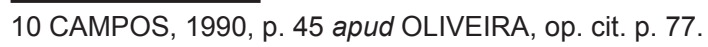


Assim, junto com a evolução econômica, houve alteração na concepção do que era família.

Na nova sociedade, não mais existe a nítida divisão de funções na família: homem e mulher, empenhados em geral no trabalho, desenvolvem suas aptidões em todos os setores possíveis; os filhos, cada vez mais liberados de condicionamento, também expandem suas potencialidades... ${ }^{11}$.

Verificou-se, então, a necessidade da criação de uma nova Constituição que acompanhasse esse crescimento social no Brasil e no mundo, que suprisse a ausência de correspondência entre as normas, fatos e valores, inclusive no Direito de Família.

Com isso, em 5 de janeiro de 1988 foi promulgada a atual Constituição Federa, que contemplou três diferentes formas de constituir família: casamento civil, casamento religioso e união estável (art. 226 e seus parágrafos). Trouxe a concepção de valorização de interesses individuais, com a proteção estatal na pessoa humana e no desenvolvimento de sua personalidade, com objetivo de formar uma família emocionalmente estruturada, buscando o equilíbrio social.

Diante da instabilidade do Código Civil de 1916 com a instituição desta nova Constituição, uma vez que trazia a antiga ideia de família a patriarcal, o legislador precisou se utilizar de leis excepcionais, necessitando de novas regulamentações acerca das relações patrimoniais privadas, bem como das novas situações surgidas no âmbito do direito de família.

Desse modo, a Constituição Federal de 1988 chamou para si o papel de lei fundamental da família, até então ocupado pelo antigo Código Civil - que perde definitivamente sua posição de centro das relações de direito privado - e pelas leis esparsas.

Visando uma união jurídica dentro do campo do Direito de Família, José Sebastião de Oliveira traz um rol de princípios constitucionais, não taxativo, que apontam pontos fundamentais os quais devem ser respeitados:

11 BITTAR, 1993, p. 9 apud ibid. p. 80. 
Proteção de todas as espécies de família (art. 226, caput); reconhecimento expresso de outras formas de constituição familiar ao lado do casamento, como as uniões estáveis e as famílias monoparentais (art. 226, §§ $3^{\circ}$ e 4\%); igualdade entre os cônjuges (art. 5०, caput, I, e art. 226, §5॰); dissolubilidade do vínculo conjugal e do matrimônio (art. 226, § 6०); dignidade da pessoa humana e paternidade responsável (art. 226, § 5०); assistência do Estado a todas as espécies de família (art. 226, § $8^{\circ}$ ); dever de a família, a sociedade e o Estado garantirem à criança e ao adolescente direitos inerentes à sua personalidade (art. 227, $\S \S 1^{\circ}, 2^{\circ}, 4^{\circ}, 5^{\circ}, 7^{\circ}$ ); igualdade entre os filhos havidos ou não do casamento, ou por adoção (art. 227, § 6 $6^{\circ}$ ); respeito recíproco entre pais e filhos; enquanto menores é dever daqueles assisti-los, criá-los e educá-los, e destes o de ampararem os pais na velhice, carência ou enfermidade (art. 229); dever da família, sociedade e Estado, em conjunto, ampararem as pessoas idosas, velando para que tenham uma velhice digna e integrada à comunidade (art. 230, CF) $)^{12}$.

Criou-se, então, o Código Civil de 2002, com um novo Capítulo referente à filiação, adequado ao modelo disposto na Constituição Federal de 1988, trazendo a impossibilidade de distinção entre as espécies de filhos, inclusive eliminando a expressão legitimidade, utilizada pelo Código Civil de 1916.

\section{OS FILHOS NOÂMBITO FAMILIAR CONTEMPORÂNEO}

Com o processo de urbanização e a atuação das mulheres no mercado de trabalho ocorrido nos meados do século XX, o conceito de família com grande número de integrantes foi se modificando, fato este que diminuiu o quadro familiar e ascendeu, consequentemente, a relação afetiva entre pais e filhos, fazendo com que quisessem permanecer mais tempo juntos.

12 lbid., p. 273. 
A união sem casamento foi se intensificando gradativamente e assim, foi sendo aceita pela sociedade. Contudo, por outro lado, também cresceu a família formada unicamente por um único membro, o pai ou a mãe.

Posto isso e tendo em vista as demais transformações sociais, o antigo modelo legal tornou-se insuficiente, cada vez mais distante da pluralidade social existente. Aquilo que constava no papel já não tinha mais tanta importância quanto nos tempos passados.

Assim, deu-se a passagem do modelo patriarcal a outro em que são dominantes as relações de solidariedade e cooperação. A perda da característica de unidade de produção, por conta da industrialização, pôs fim ao papel econômico da família, transferindo sua função relevante ao âmbito espiritual. Sua rígida concepção deu lugar à sensibilidade. A família moderna, em oposição àquela, valoriza um elemento abstrato, que até então estava à sombra: o sentimento.

$[\ldots]$

A família moderna nasce sob a concepção eudemonista, centrada nas relações de sentimento entre seus membros e baseada em uma comunhão de afeto recíproco. Enquanto a família ditada pelo Código Civil de 1916 se define como hierarquizada e de feição transpessoal, em outro momento e contexto político-econômico, a Constituição Federal de 1988 trouxe em seu texto definições que consagram a pluralidade familiar, a igualdade substancial e a direção diárquica ${ }^{13}$.

Percebe-se que, anteriormente, a regulamentação legal da família voltava-se para a máxima proteção da paz doméstica, com o casamento como instituição essencial. Hoje, a comunidade familiar deve ser preservada como instrumento de tutela da dignidade da pessoa humana, trazida pela Constituição atual,

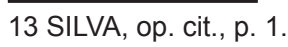


elevando a proteção à pessoa ao status constitucional. Juntamente, a Carta Magna traz a proteção à família contemporânea, sob suas diversas formas de constituição, matrimonializada ou não, constituída por ambos os genitores e filhos ou de caráter monoparental, originada por laços de sangue ou por meio de adoção.

Na mesma seara, também estão sob proteção constitucional os filhos provenientes ou não do casamento, uma vez que se tem como determinante o vínculo afetivo construído entre eles e os pais, decorrentes das relações paterno-filiais.

A evolução histórica da família, reflexo dos movimentos sociais e do processo de industrialização crescentes, deixou de ser patriarcal para tornar-se uma família nuclear da sociedade industrial contemporânea.

A Constituição Federal de 1988 reunificou o sistema, trazendo uma nova fase para o Código Civil, de valoração e interpretação junto as diversas normas espalhadas por nossa legislação, valorizando os interesses individuais, com a proteção estatal na pessoa humana e no desenvolvimento de sua personalidade, com objetivo de formar uma família emocionalmente estruturada, visando o equilíbrio social.

Um destaque é o art. 226, caput, da Constituição que, ao prever que 'a família, base da sociedade, tem especial proteção do Estado", comprometese pela sua integridade. Adota, ao longo de seus parágrafos, a concepção eudemonista, equiparando-a e reconhecendo efeitos jurídicos à união estável entre homem e mulher $\left(\S 3^{\circ}\right.$ ) e ao grupo monoparental, em que vive apenas um dos genitores e descendentes, filhos ou netos $\left(\S 4^{\circ}\right)$. Constitui "uma Constituição de cunho marcadamente compromissário, mas que erigiu a dignidade da pessoa humana à condição de fundamento de nosso Estado democrático de Direito ${ }^{14}$.

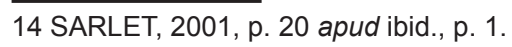


Com isso, as figuras desamparadas pelo Código Civil de 1916 passam a ser protegidas no âmbito familiar pelo txto constitucional.

Ainda, em seu artigo 227, \& 6ª a Constituição trouxe igualdade entre os filhos, quando estabelece que "os filhos, havidos ou não da relação do casamento, ou por adoção, terão os mesmos direitos e qualificações, proibidas quaisquer designações discriminatórias relativas à filiação". Mesmo que implicitamente, derrogou todos os dispositivos do sistema jurídico que fizessem distinções entre os filhos, concebendo, desta forma, um novo direito fundamental, baseado no princípio da dignidade humana, o qual todos devem respeitar.

A filiação foi um dos pontos mais alterados. Exclui-se os termos legítimos e ilegítimos, eliminando a ligação entre o casamento e a legitimidade da família. Quanto à evolução da família, a Constituição promulgou o princípio da isonomia, ao proclamar que marido e mulher são iguais em direitos e obrigações, além de igualar os efeitos jurídicos de todas as situações catalogadas como família.

Dessa forma, a Carta Magna não só permitiu o reconhecimento da paternidade em qualquer que seja o estado civil do declarante, bem como pôs fim a qualquer dúvida que persistisse a respeito dos direitos dos filhos incestuosos ou adotivos. Essa nova realidade, procedente desta evolução histórica do Direito de Família, é explicada por Fachin:

Marido e mulher, mesmos direitos e deveres. Filhos tidos dentro do casamento, mesmos direitos e deveres que os tidos fora do casamento. Assim opera a Constituição de 1988. Tendência de "constitucionalização" do Direito de Família, fruto recente. A Constituição de 1824 tratava somente da família imperial, e proclamada a República, a Constituição trazia um dispositivo sobre a matéria, tentando operar uma separação entre o poder da Igreja e o poder do Estado, e até a Constituição Federal de 1988, a lei fundamental da família era o 
Código Civil brasileiro. Em 1988, há uma guinada fundamental, a legislação infraconstitucional acaba sendo recolhida, no plano dos princípios básicos, pelo capítulo da família na Constituição Federal. $\mathrm{Na}$ incompatibilidade, não há recepção por inconstitucionaldade superveniente ${ }^{15}$.

Com o advento do Estatuto da Criança e do Adolescente, em 1990, promulgado pela Lei n. 8.069, o princípio da dignidade da pessoa humana é concretizado, corroborando sua abrangência em prol dos interesses das crianças e adolescentes, além de destacar a proteção à família natural, entendida como "a comunidade formada pelos pais ou qualquer deles e seus descendentes" e consagra a igualdade da filiação, bem como o direito de seu reconhecimento, disposto em seus artigos 26 e 27:

Art. 26. Os filhos havidos fora do casamento poderão ser reconhecidos pelos pais, conjunta ou separadamente, no próprio termo de nascimento, por testamento, mediante escritura ou outro documento público, qualquer que seja a origem da filiação.

Parágrafo único. O reconhecimento pode preceder o nascimento do filho ou suceder-lhe ao falecimento, se deixar descendentes.

Art. 27. O reconhecimento do estado de filiação é direito personalíssimo, indisponível e imprescritível, podendo ser exercitado contra os pais ou seus herdeiros, sem qualquer restrição, observado o segredo de Justiça.

Vale salientar ainda que:

Às três espécies familiares equiparadas pelo texto constitucional para fins de proteção estatal família legítima, criada pelo casamento; união estável, decorrente da união de um homem com uma mulher ausente o vínculo matrimonial; e

15 FACHIN, Luiz Edson; LIRA, Ricardo Pereira (coord.). Elementos Críticos do Direito de Família: Curso de Direito Civil. Rio de Janeiro : Renovar, 1999, p. 35. 
família natural, ou comunidade familiar, formada por ambos os genitores ou apenas um deles e seus descendentes - uniu-se outra, introduzida no sistema jurídico pelo Estatuto da Criança e do Adolescente: a família substitutiva, na qual a criança é colocada, na falta ou em lugar daquela em que nasceu, para receber melhores condições de vida, e na qual assume integralmente o papel de filho ${ }^{16}$

Contudo, no caso de filho havido fora do casamento, havendo o reconhecimento voluntário ou por sentença judicial, a paternidade pode ser estabelecida. Já os filhos concebidos no casamento sofrem a incidência da presunção pater is est. Ensina Venosa que "Apesar da igualdade estabelecida em lei, os filhos havidos fora do casamento não gozam da presunção de paternidade outorgada aos filhos de pais casados entre si" ${ }^{17}$.

Essa diferenciação ocorre em razão de a Constituição ter mantido o casamento como fonte da família, tendo como distinção entre os filhos provenientes e os não provenientes do casamento a presunção pater is est, sem que com isso fira o princípio da igualdade.

José Bernardo Ramos Boeira ensina que:

(...) a opção da unidade da filiação, tendo por base o princípio da igualdade entre os filhos nascidos fora do casamento e os filhos nascidos dentro do casamento, não fez desaparecer a distinção existente entre filhos legítimos e ilegítimos, como resultante necessário, natural e automático do casamento (...) presente em todas as legislações. Então o que a Constituição não permite é o tratamento discriminatório ${ }^{18}$.

Diante de toda a alteração ocorrida em torno do direito de família e, consequentemente, acerca do reconhecimento da

16 SILVA, op. cit., p. 1.

17 VENOSA, Silvio de Salvo. Direito Civil. 3.ed. São Paulo : Atlas, 2003. v. 6, p. 289. 18 BOEIRA, José Bernardo Ramos. Investigação de Paternidade, Posse do Estado de Filho. Porto Alegre: Livraria do Advogado, 1999, p. 21-22. 
paternidade dos filhos nascidos dentro ou fora do casamento, trouxe uma nova reflexão ao mundo jurídico e social. A paternidade jurídica, até então considerada, unicamente, a do ponto de vista biológico, passou a andar ao lado da dúvida sobre o que realmente seria a verdadeira paternidade, atentando para a realidade afetiva que liga um filho a um pai.

Apesar de incerto, o aspecto socioafetivo da filiação, tem se tornado muito mais capaz de revelar quem são os pais, pois "A verdadeira paternidade decorre mais de amar e servir do que de fornecer material genético" 19 .

Conclui-se, então, que são três as formas de se buscar a real filiação do indivíduo: a biológica, a socioafetiva e a verdade jurídica, esta proveniente da presunção de paternidade dos filhos havidos por fecundação artificial homóloga, concepção artificial homóloga e inseminação artificial heteróloga (art. 1.597, III, IV e V, do Código Civil), tida através de um laudo de DNA cujo resultado revela com precisão quase que absoluta a origem genética de uma pessoa, e por seguinte, o seu verdadeiro genitor.

A concepção eudemonista traduz a verdade sócioafetiva, consistente na própria valoração do sujeito. $\mathrm{O}$ afeto deve ser apreciado por tomar lugar de destaque no reconhecimento das relações paterno-filiais, tornando a família instrumento de realização de quem a compõe.

\section{PRESSUPOSTOS, EVOLUÇÃOEORECONHECIMENTO DA PATERNIDADE SOCIOAFETIVA}

Atualmente, os progressos científicos no âmbito da genética, especialmente os exames de DNA, permitem a identificação consangüínea do genitor e com isso a possibilidade de atribuir-lhe a responsabilidade da paternidade. Nesse norte, nossa Constituição Federal garante um tratamento igualitário a qualquer tipo de filiação, assegurando o direito, a toda criança,

19 CARBONERA, Silvana Maria. O Papel Jurídico do Afeto nas Relações de Família. In: FACHIN, Luiz Edson. (coord.). Repensando Fundamentos do Direito Civil Brasileiro Contemporâneo. Rio de Janeiro: Renovar, 1998, p. 304. 
de conhecer suas origens, sua identidade biológica e civil e seus parentes consangüíneos.

Contudo, ainda que se possa identificar a origem genética dos indivíduos, isso não assegura a construção de laços sólidos de solidariedade e responsabilidade entre pais e filhos. Conforme ensina Luana B. Silva, com relação ao reconhecimento biológico, "A filiação estabelecida por esta via, por vezes, não significará nada mais do que a menção, na certidão de nascimento, da paternidade, e a conseqüente possibilidade de reivindicação de direitos patrimoniais"20.

Nessa mesma linha de pensamento, tem-se que a filiação "emerge da construção cultural e afetiva permanente, que faz na convivência e na responsabilidade. $\mathrm{O}$ afeto não é fruto da biologia. Os laços de afeto e de solidariedade derivam da convivência e não do sangue" 21 .

Ainda, de acordo com o doutrinador Welter, há controvérsias, no cenário jurídico brasileiro, acerca de três formas de perfilhação. São elas: a formal (art. 338, do CC); a biológica (art. 227, § $6^{\circ}$, da CF); a sociológica (art. 227, § $7^{\circ}$, da CF) ${ }^{22}$.

Assim, reconhecida constitucionalmente, a filiação sociológica é a família afetiva traduzida na efetiva posse do estado de filho.Pode-se dizer que o real vínculo relacional entre pai e filho se origina pela vontade de ser pai ou mãe e não simplesmente através de um documento que informa que são seus pais biológicos.

Verificando essa nova forma de paternidade, pertinente é a observação de Madaleno, feita antes mesmo da entrada em vigor do Novo Código e que hoje se confirma:

A Carta Política de 1988 garante a todos os filhos o direito à paternidade, mas este é o sutil detalhe, pois que se limita ao exame processual e incondicional da verdade biológica sobre a verdade jurídica. Entretanto, adota um comportamento jurídico perigoso, uma vez que dá prevalência à

20 SILVA, op. cit., p. 2.

21 LÔBO, 2009 apud WELTER, Belmiro Pedro. Igualdade entre as Filiações Biológica e Socioafetiva. São Paulo : Revista dos Tribunais, 2003, p. 127-128.

22 Ibid., p. 113. 
pesquisa da verdade biológica, olvidando-se de ressaltar o papel fundamental da verdade socioafetiva, por certo, a mais importante de todas as formas jurídicas de paternidade, pois, seguem como filhos legítimos os que descendem do amor e dos vínculos puros de espontânea afeição e, para esses caracteres a Constituição e a gênese do futuro Código Civil nada apontam, deixando profunda lacuna no roto discurso da igualdade, na medida em que não protegem a filiação por afeto, realmente não exercem a completa igualização" ${ }^{23}$.

Percebe-se então que, no Brasil, a doutrina jurídica avançou substancialmente acerca da paternidade (e filiação) socioafetiva, especialmente após a Constituição Federal de 1988, uma das mais avançadas do mundo em matéria de relações familiares, cujas linhas fundamentais projetaram-se no Código Civil de 2002, uma vez que não havia mais como continuar interpretando o Direito de Família sob a ótica do Código Civil de 1916.

Devido à constitucionalização, no Direito de Família contemporâneo, vive-se um momento em que há duas vozes soando alto: a voz do sangue (DNA) e a voz do coração (AFETO). (...) No entanto, o elo que une pais e filhos é, acima de tudo, socioafetivo, moldado pelos laços de amor e solidariedade, cujo significado é muito mais profundo do que o do elo biológico ${ }^{24}$.

Segundo Paulo Luis Netto Lôbo:

O ponto essencial é que a relação de paternidade não depende mais da exclusiva relação biológica entre pai e filho. Toda paternidade é necessariamente socioafetiva, podendo ter origem biológica ou não-biológica; em outras palavras, a paternidade socioafetiva é gênero do qual são espécies a paternidade biológica e a paternidade não-biológica ${ }^{25}$.

23 MADALENO, Rolf Hanssen. Novas Perspectivas no Direito de Família. Porto Alegre : Livraria do Advogado, 2000, p. 40.

24 ALMEIDA, Maria Christina. A Paternidade Sócioafetiva e a Formação da Personalidade. O Estado e os Estados de Filiação. Belo Horizonte/IBDFAM: Revista Jurídica, n. 8, 2002, p. 24.

25 LÔBO, op. cit., p. 1 
Para o doutrinador Madaleno:

(...) a paternidade tem um significado mais profundo do que a verdade biológica, onde o zelo, o amor paterno e a natural dedicação ao filho revelam uma verdade afetiva, uma paternidade que vai sendo construída pelo livre desejo de atuar em interação paterno-filial, formando verdadeiros laços de afeto que nem sempre estão presentes na filiação biológica, até porque, a paternidade real não é biológica, e sim cultural, fruto dos vínculos e das relações de sentimento que vão sendo cultivados durante a convivência com a criança ${ }^{26}$.

É preciso compreender que a paternidade não diz respeito unicamente ao provimento de alimentos ou a direitos sucessórios. Engloba a constituição de valores e da singularidade da pessoa e de sua dignidade humana, adquiridos principalmente na convivência familiar durante a infância e a adolescência. É construída na relação afetiva e que assume os deveres de realização dos direitos fundamentais da pessoa em formação "à vida, à saúde, à alimentação, à educação, ao lazer, à profissionalização, à cultura, à dignidade, ao respeito, à liberdade e à convivência familiar" (art. 227 da Constituição). Assim, o pai é aquele quem assumiu esses deveres, ainda que não seja o que contribuiu geneticamente para a sua criação biológica, ou seja, seu genitor.

O estado de filiação se estabelece entre o filho e aquele quem assume os deveres de paternidade, que correspondem aos direitos mencionados no art. 227 da Constituição. $O$ estado de filiação é a qualificação jurídica dessa relação de parentesco, compreendendo um complexo de direitos e deveres reciprocamente considerados. Onde houver paternidade juridicamente considerada haverá estado de filiação, sendo este presumido em relação ao pai registral.

Com isso, tem-se que a afetividade tornou-se um princípio jurídico, com força normativa, impondo dever e obri-

26 MADALENO, op. cit., p. 40 
gação aos membros da família, peculiarizando o princípio da solidariedade. Além dos fundamentos contidos nos artigos 226 e seguintes da Constituição, ressalta o dever de solidariedade entre os membros da família (art. 3ㅇ, I, da Constituição), reciprocamente entre pais e filho (art. 229) e todos em relação aos idosos (art. 230).

Sobre o reconhecimento da paternidade socioafeitva, Luana B. Silva explica que:

(...) caracteriza-se pela reunião de três elementos clássicos, a saber: a utilização pela pessoa do nome daquele que considera pai, o que faz supor a existência do laço de filiação; o tratamento, que corresponde ao comportamento, como atos que expressem a vontade de tratar como faria um pai, e a fama, que constitui a imagem social, ou seja, fatos exteriores que revelam uma relação de paternidade com notoriedade - a pessoa aparenta à sociedade ser filho do pretendido pai. Essas circunstâncias, reveladas pela convivência, constituem os elementos do que se denominou posse de estado de filho.

O fato de o filho nunca ter usado o nome do pai não descaracteriza a posse de estado, se concorrerem os demais elementos citados. Cabe esclarecer que não há hierarquia entre eles, pois ainda se consideram outras qualidades que devem revestir a aparência de filho. Busca-se a publicidade, a continuidade e a ausência de equívoco na relação entre pai e filho"27.

Entretanto, conforme leciona Boeira, é de se lamentar que o legislador brasileiro não contemple expressamente "a posse de estado como suporte fático para construir a filiação quando a inexistência ou insuficiência de título se fazem presentes". Dessa forma, ao aplicador do direito cabe acolher esta realidade, e juntamente com a jurisprudência, "construir o caminho que levará à normatização com integração plena e expressa da Posse de Estado dentro do nosso sistema jurídico" ${ }^{28}$. 
Contudo, caso reconhecida a paternidade ou maternidade, voluntária ou judicial, estabelecido o vínculo afetivo, pouco importando a questão biológica, produz-se efeitos morais e patrimoniais na relação.

Portanto, toda vez que um estado de filiação estiver constituído na convivência familiar duradoura, com a decorrente paternidade socioafetiva consolidada, seja por meio de adoção judicial, de reconhecimento voluntário ou judicial da paternidade ou maternidade ou de 'adoção à brasileira', esta não poderá ser impugnada nem contraditada. A posse de estado de filho se exterioriza pelos fatos e não pelo fator biológico.

Considerando que a Constituição Federal engendrou a unidade da filiação, assim como a irrevogabilidade da adoção, que é uma forma de filiação socioafetiva (em suas varias modalidades, conforme consta no inicio deste capitulo), conclui-se que a filiação sociológica também é irrevogável. Isso porque, além de ter assento constitucional (arts. 226 , $\S \S 4^{\circ}$ e $7^{\circ}$, e $227, \S 6^{\circ}$ ), devem ser observados os princípios da prioridade e da prevalência absoluta dos interesses da criança e do adolescente, conforme art. 227, caput, da Carta Magna, e arts. $1^{\circ}, 6^{\circ}, 15$ e 19 , entre outros, do ECA ${ }^{29}$.

Logo, é incabível o fundamento da investigação da paternidade biológica, a fim de contraditar a paternidade socioafetiva já existente, pois, além de ser necessário preservar os interesses do menor, com base no princípio da dignidade da pessoa humana, esta é uma construção cultural e não um dado da natureza.

Com efeito, para Zeno Veloso, permitir que o pai, a seu bel-prazer, pudesse, a qualquer tempo, desfazer o reconhecimento da paternidade de um filho seria uma extremada injustiça, caracterizando um gesto 'reprovável, imoral, sobretudo se o objetivo é fugir do dever de alimentos, ou para evitar o agravante de parentesco num crime, por exemplo"'30.

29 WELTER, op. cit., p. 137.

30 VELOSO, 1999 apud Ibid. p. 138. 
No caso de reconhecimento voluntário da paternidade, a revogação dar-se-á apenas em razão de dolo, erro, coação, simulação ou fraude. Isso porque, uma vez reconhecida a paternidade, mesmo não sendo seu filho biológico, emerge o estado de filho sociológico, já que o educa e cria como se seu filho fosse.

Assim, a ação de investigação de paternidade só é cabível enquanto não houver esta filiação afetiva, podendo a paternidade genética ser investigada para todos os efeitos jurídicos. Todavia, excepcionalmente, para fins de impedimentos matrimoniais e em relação a vida e a saúde do filho e dos pais biológicos, a ação de investigação de paternidade será permitida.

Ressalta-se por fim, que o reconhecimento da filiação, biológica ou sociológica, é direito personalíssimo, indisponível e imprescritível, podendo ser exercido contra os pais ou seus herdeiros, sem qualquer restrição, conforme assegurado pelo art. 27 do ECA.

\section{OS EFEITOS JURÍDICOS DECORRENTES DA PATERNIDADE SÓCIOAFETIVA: REFLEXÕES ACERCA DA QUESTÃO ALIMENTAR}

\subsection{Os Efeitos Jurídicos Decorrentes da Paternidade Sócioafetiva}

Como já amplamente dito, a Constituição Federal de 1988 estabeleceu a igualdade entre os filhos. Este capítulo deste trabalho tem por objetivo expor os efeitos desta unificação que tem como único fim aniquilar as discriminações, concedendo uniformemente os direitos advindos da relação paterno-filial.

Enaltecendo o espírito de colaboração entre os membros da família, baseados no conceito eudemonista recepcionado pela nossa Lei Maior, o art. 229 traz que "Os pais têm o dever de assistir, criar e educar os filhos menores, e os filhos maiores têm o dever de ajudar e amparar os pais na velhice, carência ou enfermidade". 
Assim, com a paridade entre os filhos, desapareceram os regimes diferentes de direitos e as dissonâncias na sucessão. Consequentemente, aos pais, cabem os mesmo direitos com relação a todos os filhos, proveniente do poder familiar, este definido como "o conjunto de direitos e deveres atribuídos aos pais, em relação à pessoa e aos bens dos filhos não emancipados, tendo em vista a proteção destes" ${ }^{31}$.

Reconhecida a posse de estado de filho como via de estabelecimento da filiação, passa-se a analisar seus efeitos jurídicos pessoais decorrentes.

O poder familiar, respaldado no princípio da igualdade entre os sexos, sem distinção dos direitos e deveres dentro da sociedade conjugal, pelo art. 21 da Lei n 8.069/90 e pelo Código Civil atual, é atribuído durante o casamento ou na constância da união estável a ambos os pais, só assumindo um com exclusividade na falta ou impedimento do outro. Esses direitos e deveres atribuídos aos pais estão reunidos no art. 384 do Código Civil de 1916 e mantidos pelo art. 1.634 do novo Código.

Juntamente com o exercício do poder familiar, os pais tem direito com relação à guarda e visitas dos filhos menores. $\mathrm{Na}$ questão da família socioafetiva, quando o pai não é o pai biológico, indaga-se se, após o rompimento do relacionamento com sua parceira, faria jus a esse direito de visitação ou guarda aos filhos desta, mesmo que não possuísse qualquer vinculação formal de paternidade com aquela prole:

Sendo derivação do poder familiar, é o liame da paternidade, em princípio, quem dita as normas para a existência de guarda dos pais sobre os filhos menores. Na falência da relação entre os pais, surge o direito de visitação, que poderá ser regulado por acordo entre as partes ou por expressa deliberação em sentença. As decisões pretorianas, após a edição do Estatuto da Criança e do Adolescente, passaram

31 FACHIN, Luiz Edson. "O Encontro entre a Verdade Jurídica e a Verdade Sociológica”. In: Estabelecimento da Filiação e Paternidade Presumida. Porto Alegre : Sérgio Antônio Fabris, 1992, p. 14. 
a engrandecer e enfocar de maneira mais destacada o denominado "interesse do menor". Por seu turno, o art. 6o da Lei no 8.069/90, destaca 'a condição peculiar da criança e do adolescente como pessoas em desenvolvimento'.

A existência de um vínculo afetivo desenvolvido entre a criança e o interessado; o assentimento da criança, quando ultrapassada a tenra idade; a inexistência de vínculo biológico entre o interessado e o menor; e a demonstração de que o rompimento do contato implicaria em transtornos ao menor, são elementos que sustentam a possibilidade do direito de visitação no caso aqui mencionado, pois permitem a conclusão pelo real interesse da criança ${ }^{32}$.

Sobre esse norte:

Observamos, pois, em nome de uma singela reflexão jurídica, que a interpretação sistemática de nossas legislações, assim efetivada pela moderna doutrina civil, tendo como fundo, necessariamente, o interesse que envolve o menor, leva-nos a concluir pela possibilidade de estabelecer-se o direito de visitação do pai considerado afetivo, em relação ao filho da mulher com quem havia convivido, particularmente nas hipóteses em que a ruptura deste contrato implicaria, inevitavelmente, no surgimento de sérios transtornos à formação da personalidade da criança ${ }^{33}$

Dentro do nosso ordenamento jurídico não há qualquer disposição normativa que assegure ao pai não biológico em poder realizar seu direito de visitação ao filho afetivo. Assim, "Como não há legislação a respeito da paternidade socioafetiva, utiliza-se, além dos princípios constitucionais fundamentais, da analogia, dos costumes e dos princípios gerais de direito (art 4\%, LICC) ${ }^{34}$.

32 SILVA, op. cit., p. 3.

33 LEITE, 1997, p. 194 apud SILVA, op. cit., p. 3.

34 GUIMARÃES. Luís Paulo Cotrim. O Direito de Visitação do Pai Não-Biológico. Revista Trimestral de Direito Civil, v. 2, ano. 1, abr./jun. 2000, p. 102. 
A criação, educação e a relação de afetividade são os indícios de uma relação de paternidade responsável, sendo que o dever principal que incumbe aos pais é o de prover elementos materiais para a sobrevivência do filho, a fim de que cresça e se torne um adulto útil à sociedade. Trata-se do zelo material e moral para que o filho fisicamente sobreviva e por meio da educação forme seu espírito e seu caráter.

Consoante com a doutrina e jurisprudência predominante, o pai registral, que reconheceu como sendo seu o filho de outra pessoa, criando laços afetivos, não pode interpor ação negatória de paternidade nem tem legitimidade para buscar a anulação de registro de nascimento, inclusive por não possui qualquer vicio que justifique o requerimento.

Nosso ordenamento jurídico equiparou a paternidade sócioafetiva à adoção, pois nos dois casos uma pessoa recebe como seu o filho de outrem, independentemente de haver laços consangüíneos entre eles.

Nesse sentido, cabe transcrever o voto do Des. Luiz Felipe Brasil Santos, em caso similar, retratando a posição do egrégio Tribunal de Justiça do Rio Grande do Sul:

Ao assumir a paternidade da alimentanda, falseando com a verdade registral, assumiu todos os deveres inerentes à paternidade, visto que seu ato constituiu uma adoção simulada, e, face ao princípio da igualdade entre os filhos, consignado na Carta Magna (art. 226, § 6 $)$, diferença alguma existe entre o filho natural e o adotivo. Ademais, é de ver que, modernamente, a paternidade não é vista exclusivamente como um fenômeno biológico, mas, acima de tudo, social, sendo prestigiada, sobretudo pela jurisprudência deste Tribunal, a paternidade sócioafetiva ${ }^{35}$.

Vale ressaltar que, no caso do próprio filho afetivo buscar a desconstituição do registro de nascimento, visando obter vantagem patrimonial de seu pai biológico, o mesmo entendi-

35 PEREIRA, 1990, v. 5, p. 211 apud SILVA, op. cit., p. 3. 
mento é aplicado. Muito embora não se possa negar o direito de uma pessoa de conhecer sua paternidade biológica, uma vez que se trata de direito personalíssimo com sua imprescritibilidade protegida pelo ECA, inclusive para os filhos maiores de idade, uma vez reconhecida a filiação socioafetiva, a identificação do pai biológico não é capaz de gerar seqüelas de ordem patrimonial.

Estabelecendo o ECA a imprescritibilidade da ação investigatória de paternidade, não estender a vedação do perecimento do direito aos maiores implica em vedação ao princípio constitucional da igualdade. Ao depois, a possibilidade de investigação não traz necessariamente seqüelas obrigacionais e patrimoniais. Reconhecida a filiação sócioafetiva, a investigação de paternidade não leva à desconstituição ou anulação do registro de nascimento, mas se limita a atender à possibilidade de se conhecer a paternidade sem gerar seqüelas de ordem patrimonial. Recurso provido por maioria. $(\text { grifo deles) })^{36}$.

Percebe-se assim, que o elo entre pais e filhos concebidos pela família eudemonista vai além do que questões simplesmente patrimoniais. A concepção de família, com suas obrigações e deveres, decorrem daquilo que se chama filiação social, afetiva, muito mais importante e significativa do que a filiação genética, baseada em exames de DNA.

\subsection{A Obrigação Alimentar Decorrente da Paternidade Socioafetiva}

O dever de prestar alimentos entre os parentes, cônjuges ou companheiros é assegurado pelo no atual Código Civil em seu art. 1.694, sempre norteado pelos princípios da razoabilidade e proporcionalidade, analisando as necessidades daquele

36 TJRS - AC n 70004989562, Rel ${ }^{a}$. Des ${ }^{a}$. Maria Berenice Dias. Sétima Câmara Cível. DJ em 23-102002. 
que pleiteia e as possibilidades de quem deve provê-los (art. 1.695, CC). Tem como fundamento a assistência e solidariedade econômica que existe entre os membros de uma família.

Consoante com o art. 1.707 do Código Civil "Pode o credor não exercer, porém lhe é vedado renunciar o direito a alimentos, sendo o respectivo crédito insuscetível de cessão, compensação ou penhora". Assim, os alimentos são irrenunciáveis, impenhoráveis e indisponíveis, além de serem imprescritíveis e intransmissiveis.

$\mathrm{Na}$ aplicação da pensão alimentícia, o juiz a determina atendendo às necessidades essenciais de moradia, alimentação, vestuário, tratamento de saúde e educação do alimentando, num valor coerente com as possibilidades financeiras do alimentante.

Contudo, a quantia fixada pode sofrer alterações, uma vez que a capacidade econômica daquele que provem ou daquele que recebe os alimentos pode se modificar, necessitando assim de um ajuste para que seja o encargo alimentar adequado à realidade (art. 1.699, CC). O binômio possibilidade-necessidade deve sempre ser verificado.

O dever de alimentar é devido em razão da relação de parentesco entre o alimentante e alimentando, baseado na obrigação moral e ética existente entre eles. Em que pese o encargo alimentar possa dar uma ideia de incentivo à ociosidade, este beneficio será concedido unicamente quando os indícios, no caso de pedido provisório, ou as comprovações apresentadas sejam hábeis para demonstrar a necessidade de quem os pede. Entretanto, há de se verificar que, sendo menor de idade, a necessidade dos alimentos é presumida em decorrência natural da impossibilidade fisiológica de geração de recursos próprios para a sua subsistência, que a criança e o adolescente, em geral, manifesta, enquanto não se encontra formada ou preparada.

O direito à vida, o princípio da dignidade da pessoa humana e os diversos preceitos alinhados 
pela Carta Magna contemplam um dever de subsistência que os parentes possuem,uns em relação aos outros, no sentido de suprirem as necessidades recíprocas. Existe, desse modo, o dever de prestar alimentos entre os parentes distanciados em grau, mas que traduz uma obrigação moral entre eles, ainda mais quando presente o vínculo afetivo. Cumpre ressaltar, ainda, que os alimentos só são devidos em função da relação de parentesco existente entre o alimentante e o alimentando ${ }^{37}$.

Face ao texto constitucional de 1988, os filhos nascidos fora do casamento possuem pensão alimentícia garantida, inclusive com proteção também no Código Civil, em seu art. 1705, cujo teor garante o direito de ação contra o genitor para obter alimentos. Contudo, nada revela acerca do pedido de pensão alimentícia nas relações afetivas, que não possuem o caráter formal da adoção, uma vez que aos adotados já existe a previsão de direitos.

Conforme já explicado, os alimentos só são devidos em função da relação de parentesco, e se esta não se encontrar provada, não haverá êxito a reclamação do requerente.

A posse de estado de filho não está elencada explicitamente em lei dentre os motivos que ensejam a investigação de paternidade. Para comprovar a relação de filiação deve-se se valer das presunções que caracterizam a paternidade socioafetiva, como por exemplo se o investigante traz o nome do investigado; se foi por ele tratado como filho; se havido como tal no ambiente social da família paterna.

Entretanto, a filiação socioafetiva pode ser admitida com base nos seguintes artigos: a) art. 1593, que diz: 'O parentesco é natural ou civil, conforme resulte de consangüinidade ou outra origem'. Esta outra origem de parentesco é justamente a sociológica (afetiva, socioafetiva, social, eudemonista); b)

37 GOMES, Fernando Guidi Quintão, dez. 2008, Disponível em: <http://www.egov. ufsc.br/portal/sites/default/files/anexos/33888-44491-1-PB.pdf> Acesso em: 208-2011. 
art. 1596, em que é reafirmada a igualdade entre a filiação (art. 227, § 6º da Constituição Federal de 1988); c) art. 1597, V, pois o reconhecimento voluntário da paternidade na inseminação artificial heteróloga não é de filho biológico, e sim de filho socioafetivo, já que o material genético não é do(s) pai(s), mas, sim, de terceiro(s); d) art. 1603, visto que, enquanto a família biológica navega na cavidade sangüínea, a família afetiva transcende os mares do sangue, conectando o ideal da paternidade e da maternidade responsável, hasteando o véu impenetrável que encobre as relações sociológicas, regozijando-se com o nascimento emocional e espiritual do filho, edificando a família pelo cordão umbilical do amor, do afeto, do desvelo, do coração e da emoção, (re)velando o mistério insondável da filiação, engendrando um verdadeiro reconhecimento do estado de filho afetivo; e) art. 1605, II, em que filiação é provada por presunções - posse de estado de filho (estado de filho afetivo). (grifo deles) $)^{38}$ (MADALENO, Rolf Hanssen. Alimentos e sua Restituição Judicial. Revista Jurídica, n. 211, p. 7, maio 1995).

Sobre este assunto segue os ensinamentos de Maria Berenice Dias:

Não basta procurar a lei que preveja a obrigação alimentar e nem condicionar a imposição do encargo à presença de uma situação que retrate paradigmas pré-estabelecidos. Ao magistrado cabe identificar a presença de um vínculo de afetividade. Dispensável, a certidão de casamento ou o registro de nascimento. A formalização dos relacionamentos é desnecessária para o estabelecimento dos vínculos afetivos e, via de conseqüência, para o reconhecimento de direitos e imposição de obrigações recíprocas ${ }^{39}$.

38 MADALENO, Rolf Hanssen. Alimentos e sua Restituição Judicial. Revista Jurídica, maio 1995, n. 211 , p. 7.

39 DIAS, Maria Berenice. Alimentos, sexo e afeto. 2008. Disponível em: <http://www. mariaberenice.com.br> Acesso em: 14-8-2011. 
Assim, a filiação fincada no vínculo afetivo não poderia ficar desprotegida. Se presentes os requisitos que viabilizam o seu reconhecimento, os efeitos jurídicos dela decorrentes devem ocorrer igualmente como qualquer outra espécie de filiação, ensejando ao filho afetivo a possibilidade de receber prestação alimentícia.

Nesse sentido, a lição de Andréa Salgado de Azevedo:

Uma vez julgada procedente a ação de investigação de paternidade e/ou maternidade sócioafetiva, decorrem os mesmos efeitos jurídicos dos arts. 39 a 52 do ECA, que são aplicados à adoção, quais sejam: a) a declaração do estado de filho afetivo; b) a feitura ou a alteração do registro civil de nascimento; c) a adoção do nome (sobrenome) dos pais sociológicos; d) as relações de parentesco com os parentes dos pais afetivos; e) a irrevogabilidade da paternidade e da maternidade sociológica; $\mathrm{f}$ ) a herança entre pais, filho e parentes sociológicos; g) o poder familiar h) a guarda e o sustento do filho ou pagamento de alimentos; i) o direito de visitas etc. ${ }^{40}$.

Estabelecida a filiação socioafetiva, não há mais qualquer vínculo de parentesco da criança com seus pais biológicos conforme se pode analogamente inferir do art. 41 do Estatuto da Criança e do Adolescente e do art. 1.626 do Código Civil de 2002.

Dentro da jurisprudência pode-se observar a tendência que se impõe a cada dia no âmbito do Direito de Família, reconhecendo a paternidade socioafetiva como relação paterno-filial com direitos e obrigações como qualquer outra.

O STJ, responsável pela uniformização da jurisprudência em se tratando de lei federal, já se manifestou, com acerto, em favor do reconhecimento da filiação socioafetiva:

40 AZEVEDO, Andréa Salgado. A paternidade sócio-afetiva e a obrigação alimentar. 2007. p. 49. Disponível em: <http://www.sare.unianhanguera.edu.br/index.php/ rdire/article/view/5/5>. Acesso em: 15-8-2011. 
Merece reforma o acórdão que, ao julgar embargos de declaração, impõe multa com amparo no art. 538, par. único, CPC se o recurso não apresenta caráter modificativo e se foi interposto com expressa finalidade de prequestionar. Inteligência da Súmula 98, STJ. O reconhecimento de paternidade é válido se reflete a existência duradoura do vínculo sócio-afetivo entre pais e filhos. A ausência de vínculo biológico é fato que por si só não revela a falsidade da declaração de vontade consubstanciada no ato do reconhecimento. A relação sócio-afetiva é fato que não pode ser, e não é, desconhecido pelo Direito. Inexistência de nulidade do assento lançado em registro civil. O STJ vem dando prioridade ao critério biológico para o reconhecimento da filiação naquelas circunstâncias em que há dissenso familiar, onde a relação sócio-afetiva desapareceu ou nunca existiu. Não se pode impor os deveres de cuidado, de carinho e de sustento a alguém que, não sendo o pai biológico, também não deseja ser pai sócio-afetivo. A contrario sensu, se o afeto persiste de forma que pais e filhos constroem uma relação de mútuo auxílio, respeito e amparo, é acertado desconsiderar o vínculo meramente sanguíneo, para reconhecer a existência de filiação jurídica. Recurso conhecido e provido ${ }^{41}$.

Consoante com este entendimento, ja se decidiu no Tribunal de Justiça de Santa Catarina que:

Tendo como foco a paternidade socioafetiva, bem como os princípios da proporcionalidade, da razoabilidade e do melhor interesse do menor, cabe inquirir qual bem jurídico merece ser protegido em detrimento do outro: o direito do pai biológico que pugna pela guarda da filha, cuja conduta, durante mais de três anos, foi de inércia, ou a integridade psicológica da menor, para quem a retirada do seio de seu lar, dos cuidados de quem ela considera pais, equivaleria à morte dos mesmos. Não se busca legitimar a reprovável conduta daqueles que, mesmo justificados por sentimentos nobres como

41 REsp n. 878.941/DF, Rela ${ }^{\text {. Min }}{ }^{\text {a }}$ Nancy Andrighi, DJU de 17-9-2007. 
o amor, perpetram inverdades, nem se quer menosprezar a vontade do pai biológico em ver sob sua guarda criança cujo sangue é composto também do seu. Mas, tendo como prisma a integridade psicológica da menor, não se pode entender como justa e razoável sua retirada de lugar que considera seu lar e com pessoas que considera seus pais, lá criada desde os primeiros dias de vida, como medida protetiva ao direito daquele que, nada obstante tenha emprestado à criança seus dados genéticos, contribuiu decisivamente para a consolidação dos laços afetivos supra-referidos ${ }^{42}$.

\section{E no Tribunal de Justiça do Rio Grande do Sul:}

(...) 2. Estando provado o vínculo jurídico de filiação, a alegação de inexistência do liame biológico é irrelevante e vazia pois não paira dúvida alguma sobre o vínculo socioafetivo, decorrente da posse do estado de filho, nem que o alimentante era o provedor do núcleo familiar. 3. Os alimentos se destinam ao atendimento das necessidades dos filhos, que são presumidas, dentro da capacidade econômica do alimentante. Recurso desprovido ${ }^{43}$.

Desse modo, "o aplicador do direito, a partir da jurisprudência, está construindo o caminho que futuramente levará à normatização com integração plena e expressa da posse do estado de filho no ordenamento jurídico brasileiro" ${ }^{\text {"4 }}$.

Após toda essa analise, verifica-se que os legisladores precisam dar uma atenção especial neste tema, que vem evoluindo substancialmente, e já encontra forte respaldo na doutrina e jurisprudência. Cabe a eles a tarefa de adequação do ordenamento jurídico brasileiro e de positivação do estado de filho afetivo em sua máxima plenitude, com todos os efeitos jurídicos a ele relacionados, sejam morais ou patrimoniais, como, por exemplo, a obrigação e o direito alimentar.

42 TJSC, AC n. 2005.042066-1, Rel. Des. Sérgio Izidoro Heil, DJ de 1-6- 2006.

43 TJRS, Al n. 70007798739, Rel. Des. Sérgio Fernando de Vasconcellos Chaves, DJ de 18-2-2004.

44 AZEVEDO, op. cit., p. 53. 


\section{CONCLUSÃO}

Numa análise histórica do conceito de família vimos primeiramente uma sociedade patriarcal, na qual o casamento era indissolúvel, a mulher devia obediência ao marido e os filhos reconhecidos eram apenas os havidos dentro de um casamento, impedindo-se qualquer possibilidade de reconhecimento de filhos fora do matrimonio. A presunção pater is est expulsou-os do convívio social e do mundo jurídico existente a sua volta.

No entanto, com o movimento de mulheres, com a queda de preconceitos, com a ascendência da dignidade da pessoa humana, a entidade familiar evoluiu. A igualdade de tratamento entre os filhos, garantida pela Constituição Federal de 1988, assegurou a toda criança de conhecer suas origens e seus parentes consangüíneos.

Assim, a justiça brasileira teve base legal para amparar as pretensões de declaração da paternidade biológica. No entanto, silenciou acerca da paternidade afetiva, proveniente de outros elementos que definiam uma relação paterno-filial, que não a genética.

É indubitável que do estado da pessoa decorrem direitos e obrigações. Entretanto, a única forma de garantia do cumprimento dos deveres que emanam do estado de pai é a vontade. A dedicação de uma pessoa para com outra só pode ser assegurada através do amor. Uma terceira verdade revelou-se, assim, no estabelecimento da filiação, identificando a figura paterna através do desvelo e serviço com que se entregava a seu filho. Pôde-se apresentar, então, três verdades na busca da real filiação: jurídica, biológica e sócioafetiva.

Hoje, a família é tida como uma relação de valorização entre seus membros. O Direito de Família reconheceu que os melhores pais nem sempre são aqueles que geram, mas sim, aqueles que criam, educam e dão afeto. São aqueles que exercem os direitos fundamentais da pessoa humana para com as 
crianças. Portanto, consagrou a paternidade sócioafetiva através da Doutrina da Proteção Integral, sobrepondo-a à biológica.

Ainda, a Constituição Federal determinou a igualdade entre os filhos de qualquer origem, na linha ideológica da concepção eudemonista. Consagrou verdade sócioafetiva, garantindo lugar de destaque ao afeto no reconhecimento das relações paterno-filiais.

O legislador brasileiro não contemplou expressamente a posse de estado como suporte fático para construir a filiação quando inexiste título para comprová-la, cabendo a jurisprudência e a doutrina enquadrá-la como um fato, integrando-a implicitamente no sistema jurídico.

Com base nessa jurisprudência, o aplicador do direito está construindo o caminho que futuramente levará à normatização com integração plena e expressa da relação socioafetiva no ordenamento jurídico brasileiro.

Estabelecido o estado de filho afetivo, dele emana direitos e deveres entre pais e filhos, morais e patrimoniais, conseqüentes do verdadeiro sentido da relação de paternidade na concepção eudemonista.

Assim, os efeitos jurídicos dessa relação afetiva enquandra também a obrigação alimentar, decorrente do dever de manutenção das necessidades básicas da criança impulsionado pelo principio da dignidade da pessoa humana e dos direitos fundamentais, ambos garantidos em nossa Constituição vigente.

Consoante o exposto, sustenta-se o surgimento de um direito para todos, sem discriminação, numa tutela social ampla, capaz de atender à realidade cultural brasileira, tornando o direito efetivo e útil em sua aplicação.

Abstract: The child's support alimony, provided to mantain the child's life, was made necessary by the principle of human dignity which comes from the current constitutional text. In such terms, this 
article is bound to enlighten topics about the affective family, their duties and obligations, comparing through analogy the affective parent to the biological one. Thus, it will be demonstrated the evolution of the brazilian legal system on family law, which, although the great improvement that has been occurred, failed to keep up with all the changes that society went through, since the lack of legal normatization on socioaffective paternity, leaves, at last, the due regulamentation for the doctrine and the jurisprudence.

Keywords: Foods. Filiation. Equality. Right. Justice.

\section{REFERÊNCIAS}

ALMEIDA, Maria Christina. A Paternidade Sócioafetiva e a Formação da Personalidade. O Estado e os Estados de Filiação. Belo Horizonte/IBDFAM: Revista Jurídica, n. 8, maio 2002.

AZEVEDO, Andréa Salgado. A paternidade sócio-afetiva e a obrigação alimentar. 2007. Disponível em: <http://www.sare.unianhanguera.edu.br/ index.php/rdire/article/view/5/5>. Acesso em: 15-8-2011.

BOEIRA, José Bernardo Ramos. Investigação de Paternidade, Posse do Estado de Filho. Porto Alegre: Livraria do Advogado, 1999.

BOSCARO, Márcio Antônio. Direito de Filiação. São Paulo: Revista dos Tribunais, 2002.

CARBONERA, Silvana Maria. O Papel Jurídico do Afeto nas Relações de Família. In: FACHIN, Luiz Edson. Repensando Fundamentos do Direito Civil Brasileiro Contemporâneo. Rio de Janeiro: Renovar, 1998.

DIAS, Maria Berenice. Alimentos, sexo e afeto. 2008. Disponível em: <http:// www.mariaberenice.com.br>. Acesso em: 17-8-2011.

FACHIN, Luiz Edson. O Encontro entre a Verdade Jurídica e a Verdade Sociológica. In: Estabelecimento da Filiação e Paternidade Presumida. Porto Alegre: Sérgio Antônio Fabris, 1992.

FACHIN, Luiz Edson; LIRA, Ricardo Pereira. Elementos Críticos do Direito de Família: Curso de Direito Civil. Rio de Janeiro: Renovar, 1999. 
FERREIRA, Luis Ferreira. Curso de Direito Constitucional. 3 ed., São Paulo: Saraiva, v. I, 1974.

GOMES, Fernando Guidi Quintão. A filiação socioafetiva e seus efeitos na obrigação de prestar alimentos. 2008. Disponível em: <http://www.egov.ufsc. $\mathrm{br} / \mathrm{portal} / \mathrm{sites} / \mathrm{default} / \mathrm{files} / \mathrm{anexos} / 33888-44491-1-\mathrm{PB} . \mathrm{pdf}\rangle$. Acesso em: 17-8-2011.

GOMES, Orlando. Direito de Família. Rio de Janeiro: Forense, 1978.

GUIMARÃES. Luís Paulo Cotrim. O Direito de Visitação do Pai

Não-Biológico. Revista Trimestral de Direito Civil, v. 2, ano. 1, abr./jun. 2000.

LÔBO, Paulo Luiz Netto. Princípio jurídico da afetividade na filiação. 2005.

Disponível em: <http://jus.uol.com.br/revista/texto/527/principiojuridico-da-afetividade-na-filiacao $>$. Acesso em: 17-8-2011.

MADAlENO, Rolf Hanssen. Novas Perspectivas no Direito de Família. Porto Alegre: Livraria do Advogado, 2000.

OLIVEIRA, José Sebastião de. Fundamentos Constitucionais do Direito de Família. São Paulo: Revista dos Tribunais, 2002.

PEREIRA, Sérgio Gischkow. Algumas Questões de Direito de Família na Nova Constituição. A Igualdade na Filiação, Inclusive para Adotados. Revista AJURIS, n. 45, v. 16, mar. 1989).

SILVA, Luana Babuska Chrapak da. A paternidade socioafetiva e a obrigação de alimentar. 2003. Disponível em: 〈http://jus.uol.com.br/revista/ texto/5321/a-paternidade-socioafetiva-e-a-obrigacao-alimentar/1>. Acesso em: 18-8-2011.

TEPEDINO, Gustavo. Temas de Direito Civil. 2.d. rev. e atual. Rio de Janeiro: Renovar, 2001.

VENOSA, Silvio de Salvo. Direito Civil. 3.ed. São Paulo: Atlas, v. 6, 2003.

WELTER, Belmiro Pedro. Investigação de paternidade socioafetiva. Porto Alegre: Sintese. Revista Brasileira de Direito de Família, n. 6, jul-ago-set, 2000.

WELTER, Belmiro Pedro. Igualdade entre as Filiações Biológica e Socioafetiva. São Paulo: Revista dos Tribunais, 2003. 